\title{
COMPARISONAL ANALYSIS OF STUDENTS' LEARNING ACHIEVEMENTS FROM IBTIDAIYAH ELEMENTARY SCHOOL AND MADRASAH IN LEARNING ISLAMIC RELIGIOUS EDUCATION AT SMP NEGERI 4 RANTAU ACEH TAMIANG REGENCY
}

\author{
Aini Safitri \\ STAIN Teungku Dirundeng Meulaboh \\ E-mail: aini.safitri133@gmail.com
}

\begin{abstract}
This study discusses the comparison of student achievement from Elementary Schools and Madrasah Ibtidaiyah in learning Islamic education at State Junior High School 4 Rantau, Aceh Tamiang district. The research conducted by the author uses a qualitative approach that is a field study of Islamic religious education learning and analyzes student achievement from two different backgrounds. The use of the method in this study is a qualitative descriptive method. Data collection is done by observation, interviews, documentation (notes or archives). Data analysis techniques include data reduction, data presentation, data verification and critical analysis. The results showed that students from both different backgrounds obtained good learning scores, good skills, and were able to apply good attitude values and uphold ethics in learning.
\end{abstract}

Keywords: Learning Achievement, Basic Education, Islamic Religious Education

\section{INTRODUCTION}

Talking about education, Islam teaches how important the meaning of educational activities is. Islamic Religious Education in Junior High School is one of the conditions that will determine the success of the implementation of Islamic education at the basic education level. Many are explained in the Koran about the importance of education. One of them is QS. Al-Alaq verses one to five, the verse actually contains the command to read and write. Reading and writing are a series of learning activities, in which there are acts of conveying, studying, exploring, researching and so on.

It has become a necessity, education in its activities is in an environment. The school environment cannot stand alone in educating children, it takes synergy and mutual support between the family and 
IJIERM: Vol. 3 No. 1 January - March 2021

community environment. These three environments are referred to as educational institutions or educational units. ${ }^{1}$ The practice of Islamic education has been going on for a long time, but in practice it varies according to the level of development of civilization and the mindset of a society. The importance of Islamic religious education in the formation of a child's personality can be a special concern from various parties, so that the goals of Islamic education itself can be achieved.

Islamic religious education is taught at the basic level of education, namely in the form of Elementary Schools and Madrasah Ibtidaiyah. Islamic religious education in elementary schools has a different curriculum content, there is a difference in the percentage of religious lessons compared to the elementary school curriculum. In the Islamic religious education curriculum at Madrasah Ibtidaiyah there are subjects that include: the Qur'an, hadith, jurisprudence, history of Islamic culture, moral creed, and Arabic. ${ }^{2}$ So that graduates from Madrasah Ibtidaiyah should be superior in learning Islamic religious education.

SMP Negeri 4 Rantau, Aceh Tamiang district, is located on the Kebun Ubi-Rantau road, Kebun Ubi hamlet, Rantau sub-district, Aceh Tamiang district. Number and date of SK Penegrian 126 of 2007 dated June 4, 2007. This school is located between Madrasah Ibtidaiyah and Elementary School (SD). Because of its location which is flanked by the two schools, the students who enroll in SMP Negeri 4 Rantau are students who have both basic educational backgrounds from Elementary School and Madrasah Ibtidaiyah.

The differences in student backgrounds between graduates from Elementary School and Madrasah Ibtidaiyah certainly affect student achievement in Islamic religious education subjects. Apart from the different curriculum factors, of course, human resource factors also affect the results. Based on this background, the researcher is very interested in examining the comparison of student achievement from Elementary School and Madrasah Ibtidaiyah in learning Islamic education at State Junior High School 4 Rantau, Aceh Tamiang district.

${ }^{1}$ Fuad Ihsan. Dasar-dasar Kependidikan. (Jakarta: Rineka Cipta, 1995), p.16

2 Curriculum structure and study load arrangements for Madrasah Ibtidaiyah Nahdatul Ulama KH. Believers according to Ministerial Regulation No.22 of 2006 concerning standard content and Circular of the Director General of Islamic Education Number: DJ. II.1/PP.00/ED/681/2006 
IJIERM: Vol. 3 No. 1 January - March 2021

\section{THEORITICAL RIVIEW}

\section{Definition of Learning Achievement}

According to the Big Indonesian Dictionary, achievement is the result of performance. ${ }^{3}$ According to the term achievement is a result obtained from a series of learning activities carried out. While learning is trying to gain intelligence or knowledge. ${ }^{4}$ Learning in the view of Gregory A. Kimble is a relatively permanent change in the potential for behavior that occurs in individuals as a result of training or practice that is reinforced by giving gifts. ${ }^{5}$ (learning as a relatively permanent change in behavioral potentiality that occurs as a result of reinforced practice).

Learning is very important in Islam, Islam punishes every Muslim and Muslim woman to learn, because learning is not just a matter of fulfilling needs and rational development, but also includes physical and spiritual needs in a balanced way. The following are some verses of the Qur'an and hadith that explain the obligation of learning for every Muslim, both explicitly and implicitly. Q.S. An-Nahl verse 78: "Meaning: And Allah brought you out of your mother's womb knowing nothing, and He gave you hearing, sight and heart, so that you may be grateful." Q.S. Az-Zumar verse 9: Meaning: ... (Say: "Are there the same people who know with those who don't know?" Verily, people who have reason can receive lessons.

People who seek knowledge will be given convenience by Allah SWT, as explained by the Prophet SAW below: Meaning: Yahya bin Yahya AtTamimi, Abu Bakr bin Abu Syaibah, and Muhammad ibn 'Ala 'Al-Hamdani have told us. And this lafazh belongs to Yahya. Yahya said: Have informed us. The other two said: Abu Mu'awiyah reported to us, from Al-A'masy, from Abu Salih, from Abu Hurairah. He said: The Prophet sallallaahu 'alaihi wa sallam said, 'Whoever relieves a believer of a difficulty from the troubles of this world, Allah will relieve him of the troubles of the Day of Resurrection. And whoever makes it easy for a person in difficulty, Allah will make it easy for him in this world and the hereafter. Whoever covers the disgrace of a Muslim, Allah will cover his disgrace in this world and the hereafter. And Allah always helps the servant as long as the servant helps his brother. And whoever takes a path in search of knowledge, Allah will make easy for him the path to Paradise. There is not a people who gather in

\footnotetext{
${ }^{3}$ https://kbbi.kemdikbud.go.id/

${ }^{4}$ Ibid.,

${ }^{5}$ Purwa Atmaja Prawira, Psikologi Pendidikan dalam Perspektif Baru, (Jojakarta: ArRuzz Media,2013) p.225-227
} 
one house from the houses of Allah, they read and study the Book of Allah among themselves, except that tranquility will descend upon them, mercy will overtake them, angels will surround them, and Allah will call them to their saints. angel by his side. Whoever slows down his deeds, his lineage will not be able to speed it up (HR. Muslim). ${ }^{6}$

From the various understandings and views above, it can be concluded that learning is a process to acquire intelligence and knowledge and to change human behavior caused by learning experiences.

So, learning achievement is a symbol of student success in their education. Measurement of student achievement is carried out in three domains, namely cognitive, affective and psychomotor. The measurement is carried out after following the learning process with test instruments both oral and written which are adjusted for relevance. The form of the results of measuring student achievement is expressed by symbols of numbers and letters or descriptions that explain the results achieved by students at a certain time. The form of learning tests in formal education activities is in the form of daily tests, mid-semester tests and end-of-semester exams as well as national exams.

Measurement of learning achievement is carried out not only to find out the high and low of a person's achievement, but in this case it is associated with the verses of the Qur'an above that Allah SWT looks up to the most pious people among His people.

\section{Factors Affecting Learning Achievement}

Seeing the factors that affect learning achievement, of course we look at it from two sides. The first is seen from the internal side and the second is viewed from the external side. Internal factors and external factors that affect learning achievement are described as follows:

\section{a. Internal Factors}

Internal factors are factors that come from within oneself, namely physical and spiritual.

1) Physical. The body is a student's physiological condition, in a healthy body there is a strong soul. Students with healthy conditions will easily follow the lesson, on the other hand students with impaired hearing, vision, and diseases in their biological organs will interfere with the student's learning process.

${ }^{6}$ Imām Abi Al-Husāin Muslim Bin al-Hajj, Shahih Muslim (Riyad Arab Saudi: Dar ‘Alimu al Kutub,1996), No. 2699. jilid IV. p. 2074. 
IJIERM: Vol. 3 No. 1 January - March 2021

2) Spiritual. Spirituality is the condition of the soul/spirit or psyche of students. Spiritual factors include intelligence, attention, talent, interest, enthusiasm/motivation. Students in a state of lack of rest, lack of sleep will experience impaired concentration in learning, students will find it difficult to focus on lessons. Likewise, students who experience problems or problems in their families will interfere with student concentration and interest. Furthermore, the food intake given is also very influential on the spiritual condition of students. The food given must be food that is good in nutrition and halal in terms of substance and how to obtain it.

\section{b. External Factors}

External factors are factors that come from outside the self, namely the environment. The environment can be divided into several parts, namely the family environment, school environment, and community environment.

1) Family Environment. John Locke (1632-1704) argues that children are born in this world as a sheet of white paper, this white paper can be written as the author wishes. Locke's view of the white sheet of man is very similar to fitrah which is based on the statement of the Qur'an, sura 30 Ar-Rum verse 30: Meaning: "So turn your face straight to the religion of Allah; (stay on) the nature of Allah who has created man according to that nature. There is no change in the nature of Allah. (That is) the straight religion; but most people don't know." (Q.S. Ar-Rum:30) Fitrah Allah means the creation of Allah. Humans were created by God to have a religious instinct, namely the religion of monotheism. Fitrah is a human innate from birth which contains three potentials with their respective functions. First, the potential of reason that functions to know God, unite God, and love Him. Second, the potential for lust that serves to induce pleasant objects. Third, the potential for ghadab which serves to avoid everything that is harmful. When humans are born, these three potentials have been possessed. However, in order for these potentials to be actualized, external assistance is needed. Both parents are first obliged to provide knowledge to optimize these potentials. It means that it is the parents who write on the white sheet of the newborn child ${ }^{7}$

${ }^{7}$ Hasan Basri, Filsafat Pendidikan Islam, (Bandung, Pustaka Setia, 2009), p.31-32 
IJIERM: Vol. 3 No. 1 January - March 2021

2) School Environment. The mission developed in the field of education is to educate the nation's life. The government organizes a national teaching system regulated by law. The national education system is organized through two channels, namely the school education path and the out-of-school education path. The education unit organizes teaching and learning activities carried out at school or outside of school. The level of education that includes the school pathway consists of basic education, secondary education, and higher education (Law No. 2 of 1989, article 9, paragraph 1; article 10 paragraph 2, article 12 paragraph 1). ${ }^{8}$ Thus the school environment is very influential in the formation of student learning achievement, it is the duty and responsibility of school leaders and educators in schools to create outputs in the world of education that excel and are useful for their environment. Educators in schools always guide the educated and seek recognition of the needs of abilities, talents, interests and so on, and create an effective situation for education. The pedagogic competence possessed by educators in schools will determine the learning achievement of students and the success of the educational process in schools.

3) Community Environment. Society is a collection of people and families who live in a certain area, carry out their lives and are bound by a mutually agreed rule and apply to their environment. The learning process occurs in people's lives. In Hasan Basri's book Philosophy of Islamic Education as stated by Beni Ahmad Saebani, in people's lives there are cultural processes as follows: ${ }^{9}$

(a) The process of mutual learning in culture through interaction in an organized society or a complex society;

(b) The process of sharing culture among members of the organization;

(c) The process of passing on culture from one generation to the next or across generations (trans and cross generation);

(d) The process of symbolizing behavior that is considered representative for organizational cultural integration;

(e) The process of forming and integrating social behavior; and

8 Tim Pakar Manajemen Pendidikan Universitas Negeri Malang, Manajemen Pendidikan, (Malang: Penerbit Universitas Negeri Malang, 2003), p. 28

${ }^{9}$ Hasan Basri, Filsafat Pendidikan Islam..., p. 48 
(f) The process of adaptation of all behaviors of institutional society, which strengthens the heterogeneity of behavior, on the other hand, weakens the dynamics of social perception and action.

From this view, it can be understood that society is a teacher for all humans. Society is the most extensive place for learning and teaching. Society influences the process of formation and learning achievement of children and society is also the main goal of education itself, namely the education obtained by children in school will be applied in social life.

\section{Factors Affecting Student Achievement Declines}

Learning achievement is part of one's competence. In general, competence can be defined as a set of knowledge, skills, attitudes, and values as performance that affects one's role, actions, achievements, and work. Thus, competence can be measured by general standards and can be improved through education and training. The author can say that the factors that affect student learning achievement decline consist of the condition of the students, the environmental factors of the students, and the factors of the students' teaching materials.

3.1. Factors Condition of students, namely:

a. Motive. Something that a person or student has to think consistently or the desire to take an action. Example: someone who is motivated will set a challenge for himself, then take responsibility for achieving that challenge and using feedback to improve it. Intrinsic motive or self-starting.

b. Innate. Physical characteristics that respond consistently to various situations or information. Emotional self-control and initiative are more complex consistent responses.

c. Self concept. A person's behavior, values, or image. An example of self-confidence. Students who are confident will be more effective in various learning situations.

d. Knowledge. Special information owned by a person or student. It is divided into two namely:

(1) Memories. According to Abu Ahmadi (1992:70), memory is the power of the soul to receive, store and produce impressions. There are three elements in the act 
of memory, namely: receiving impressions, storing, and producing.

(2) Response. Response is the extent to which students can receive stimuli and respond to knowledge tests.

e. Skills. Ability to perform tasks physically or mentally. ${ }^{10}$

\subsection{Student Environmental Factors}

As previously explained, the student environment consists of the school, family and community environment. Unfavorable relationships between students and people in the school environment, such as: unfavorable relationships between students and teachers, or students with other friends will cause discomfort to students, thus affecting the process of students in digesting and understanding lesson.

Likewise, disharmony in the relationship between families, will cause students to experience frustration and find it difficult to learn. Not infrequently students who excel will experience depression so that their learning achievement decreases due to conflicts in the family environment.

The community environment also plays a role in increasing student achievement, an unfavorable environment, unhealthy relationships will cause students to be unmotivated and tend to be lazy to learn. So that a good environment, good friends, good association, is very necessary in placing students in the community.

\subsection{Factors of Student Teaching Materials}

Student teaching materials are very important as part of educational planning in the whole educational process. Wellplanned teaching materials provide clarity of direction in the business process of providing education. With this clarity of direction, educational efforts will be carried out more effectively and efficiently ${ }^{11}$

Teachers who are creative and innovative in developing teaching materials play a very important role in developing the potential of students. On the other hand, teachers who are lazy to plan and develop teaching materials will make the learning

${ }^{10}$ Ella Yulaelawati, Kurikulum dan Pembelajaran (Jakarta: Pakar Raya, 2007)

11 Saud Syaefudin and Syamsuddin Makmun Abin, Perencanaan Pendidikan, (Bandung, PT. Remaja Rosda Karya. 2009). p. 42 
atmosphere ineffective so that students will feel lazy to learn, so that the good potentials of students cannot be explored to the maximum and affect the development of student achievement.

\section{Achievement Improvement Theories}

In general, there are known fundamental theories that can be used in learning. Any curriculum cannot adhere to one theory as a whole by ignoring the other basic theories. ${ }^{12}$

4.1. Behaviorism Theory

Summary of the theory of behaviorism put forward by Pavlov, Thorndike, Watson, and Skinner, namely: 1). Emphasizes attention to changes in behavior that can be observed after a person is given a treatment; 2). Behavior can be strengthened or stopped through rewards or punishments; 3 ). Teaching is planned by setting up measurable or observable instructional objectives; 4). The teacher does not need to know what knowledge is already known and what happens to a person's thinking process.

The implications of behaviorist theory in education are profound. The teacher writes instructional objectives in preparation for teaching, which will then be measured at the end of the lesson. The teacher does not pay attention to what students already know, or what students think during the teaching process. The teacher sets the strategy by giving rewards (in the form of high marks or praise) and punishments (low marks or other punishments). The teacher emphasizes more on what behavior students must do, not on students' understanding of something.

\subsection{Cognitivism Theory}

The summary of the theory of cognitivism is: 1). All ideas and images are represented by schemas; 2) if the information according to the scheme will be accepted, otherwise it will be adjusted or the scheme adjusted; 3 ). Learning involves mastery or realignment of cognitive structures in which a person processes and stores information.

Adherents of cognitive theorists recognize that learning involves associations that are built through association or repetition. They also recognize the importance of reinforcement

\footnotetext{
${ }^{12}$ Ella Yulaelawati, Kurikulum..., p. 60
} 
IJIERM: Vol. 3 No. 1 January - March 2021

(reinforcements), although more emphasis on providing feedback (feedback) on the correct response in its role as a motivator (motivator). Although accepting some of the concepts from behaviorists, cognitive theorists view learning as involving mastery or rearrangement of the cognitive structures in which a person processes and stores information.

\subsection{Constructionism Theory}

According to Schuman (1996), constructivity is put forward on the premise that all people construct their view of the world through individual experiences or schemas. Constructive emphasizes on preparing students to face and solve problems in uncertain or ambiguous situations.

In summary, the theory of constructivism is: 1). Learning is the construction of knowledge based on previous experience or knowledge; 2). Learning is one's interpretation of the world; 3). Learning is an active process in which knowledge is developed based on experience and negotiation (negotiation) of meaning through sharing information or seeking agreement from various perspectives through interaction or collaboration with others; 4 ). Learning needs to be placed in a real setting. ${ }^{13}$

\section{RESEARCH METHODS}

This research is a qualitative research. Using a qualitative descriptive method that describes the learning achievement of students from Elementary Schools and Madrasah Ibtidaiyah in Islamic religious education subjects.

Collecting data using interviews, observations, and documents (notes or archives). Interviews, participant observation and document review support and complement each other in meeting the required data as the focus of the research. The data collected is recorded in field notes.

The data obtained from the research sites were analyzed using an interactive model from Miles and Huberman (1994) by compiling data, connecting data, reducing data, presenting data, drawing conclusions/verification during and after data collection. ${ }^{14}$ The analysis took place in a circular manner and was carried out throughout the study.

13 Ibid..., p. 63-66

14 Salim dan Sahrum, Metodologi Penelitian, (Bandung. Citapustaka Media, 2012). p. 
IJIERM: Vol. 3 No. 1 January - March 2021

In the early stages of data collection, the focus of research is still wide and not clear, while observations are still general and broad. After the focus became clearer, the researcher used more structured observations to obtain more specific data.

\section{RESEARCH RESULT}

The learning achievement of students from Elementary Schools and Madrasah Ibtidaiyah in learning Islamic religious education in junior high schools can be seen and measured from the extent to which students' success in mastering the material provided by the teacher, academic potential abilities and practice of attitudes.

Sources of data for comparative analysis of student achievement from elementary schools and Islamic elementary schools in learning Islamic religious education in junior high schools, one of which was obtained from interviews with Islamic religious education teachers at SMP Negeri 4 Rantau. He stated that: students who come from the educational background of Madrasah Ibtidaiyah are on average able to master the subject matter of Islamic religious education well, this is because the curriculum of Madrasah Ibtidaiyah is added with fiqh lessons, the Koran hadith, the history of Islamic culture, creed, and morality, and Arabic, so that students can easily master Islamic religious education materials in junior high schools because of their academic potential. On the other hand, students who come from elementary schools do not master Islamic religious education material to the maximum because the Islamic religious education they get in elementary school is very minimal, only 4 hours per week. So that the differences in the learning achievement of Islamic religious education owned by students who come from these two different backgrounds will clearly be seen.

The same thing was also expressed by the school principal, there is a difference between the learning achievements of Islamic religious education students with different basic education backgrounds. This was known for the first time during the Friday activity with reading Yasin in the morning. It was found that some students could not read the Koran. Furthermore, in the practice of worship, some students were not able to pray properly and correctly, both in terms of reading and movement.

According to teachers in the field of curriculum, in relation to learning achievement of Islamic religious education, learning achievement of Islamic religious education is very important for students. If Islamic religious education is good, then religious practices and the application of 
IJIERM: Vol. 3 No. 1 January - March 2021

attitudes to students will be attached, so that it has a good effect on all subjects. In this case, Islamic religious education teachers and the school curriculum team seek good educational planning for the ongoing Islamic religious education in schools. Teachers make learning innovations with varied methods so that students are eager to learn.

The school has a target so that students are able to read the Koran, practice worship, and be able to realize the practice of good attitudes. The school makes a screening for students whose understanding of Islamic religious education is minimal, then runs a religious extracurricular program that is held in the afternoon. In the activities carried out the practice of worship and learning the Koran and religious literacy. Furthermore, every Friday morning the joint yasin activities continued. Before it was time to go home, the congregational midday prayer was held in the school prayer room, and it was closed with a cult activity by the teacher. Extracurricular programs and religious activities outside of school hours are intended to increase the shortage of hours in Islamic religious education subjects in schools, considering that Islamic religious education in junior high schools is only 3 hours per week.

Seeing that the condition of students is not in accordance with the school's vision and mission, namely realizing Indonesian people who like to study actively, creatively, and innovatively, and have noble faith and morals. The mission of the school is to provide quality education for the community, produce students who excel and are able to compete in the era of globalization, realize and develop public schools with Islamic nuances, and produce students who are knowledgeable, faithful and pious.

The benefits obtained after implementing learning innovations and extracurricular activities, some students who come from elementary schools who have minimal Islamic religious education achievements can increase achievement. Students are able to improve the reading of the Koran, the implementation of good worship practices, and the application of good attitude values.

And this can also be seen from the achievement of the Minimum Completeness Criteria (KKM) for Islamic religious education subjects. Students from Elementary Schools achieved an average score of 79.8, and students from Madrasah Ibtidaiyah were 82. Both grades were included in the category of complete scores when measured from the Minimum Grade Completeness Criteria, which was 70 in the subject of Islamic Religious Education, only a difference of 2.2, as well as the attitude value between the 
IJIERM: Vol. 3 No. 1 January - March 2021

two there is no very sharp difference, both groups of students have a good average attitude score.

This study also obtained the full participation of teachers and parents in student learning activities. Students receive religious learning not only at school but at home with the guidance of their parents, in places of study under the guidance of the Koran teacher, and in the community through the practice of religious activities. In addition, teachers teach with the right method and good planning. Teachers understand the basic concept of education which is an effort that can accelerate the development of human potential and affect physical, mental, emotional, moral development, as well as faith and piety.

\section{CONCLUSION}

The learning achievement of students from Elementary Schools and Madrasah Ibtidaiyah in learning Islamic religious education at State Junior High School 4 Rantau Aceh Tamiang district after participating in Islamic religious education learning at school is good. There is no sharp difference between students from the two different basic education backgrounds. The two groups of students from different basic educational backgrounds were able to achieve good achievements in learning Islamic religious education. Students are able to practice good reading of the Koran, good understanding of subject matter, good worship practices, and the application of attitude values which are manifestations of students' moral aqidah. Schools and teachers have a high commitment in an effort to encourage the success of students even though they come from different basic educational backgrounds but must achieve equally good learning achievements in Islamic religious education.

Teachers have applied appropriate methods in teaching and delivering Islamic Religious Education materials in schools. This can be seen from the difference in value which is not too significant between the two different basic educational backgrounds of students. Of course this can happen because the teacher teaches appropriately and full of appreciation so that students feel motivated and race each other in the spirit of learning.

The community environment, and the participation of parents who also work in synergy with schools in supporting student achievement in Islamic religious education subjects in order to create human beings who excel and are able to compete in the era of globalization, realize and develop public schools with Islamic nuances, and produce knowledgeable students broad, faithful and pious. 
IJIERM: Vol. 3 No. 1 January - March 2021

\section{Bibliografhy}

Ahmadi, A. 1992. Psikologi Umum Cet.I. Jakarta: PT. Rineka Cipta

Fuad Ihsan. Dasar-dasar Kependidikan .(Jakarta: Rineka Cipta, 1995)

Hasan Basri, Filsafat Pendidikan Islam, Bandung, Pustaka Setia, 2009

Imām Abi Al-Husāin Muslim Bin al-Hajj, Shahih Muslim (Riyad Arab Saudi:

Dar 'Alimu al Kutub,1996), No. 2699. jilid IV.

PurwaAtmajaPrawira,Psikologi Pendidikan dalam Perspektif

Baru,Jojakarta,Ar-Ruzz Media,2013

Salim dan Yahrum, 2012. Metodologi Penelitian. Bandung. Citapustaka Media

Saud Udin Syaefudin dan Syamsuddin Makmun Abin, Perencanaan Pendidikan, Bandung, PT. Remaja Rosda Karya. 2009.

Struktur kurikulum dan pengaturan beban belajar Madrasah Ibtidaiyah Nahdatul Ulama KH. Mukmin sesuai Peraturan Menteri No.22 tahun 2006 tentang standart isi dan surat Edaran Dirjen Pendidikan Islam Nomor: DJ. II.1/PP.00/ED/681/2006.

Tim Pakar Manajemen Pendidikan Universitas Negeri Malang, Manajemen

Pendidikan, Penerbit Universitas Negeri Malang, 2003

Yulaelawati Ella. Kurikulum dan Pembelajaran. Jakarta: Pakar raya. 2007

https://kbbi.kemdikbud.go.id/ 